\title{
EFFECTS OF EXTRACTED WHEAT GERM OIL IN SHEEP AND CATTLE*
}

\author{
W. RICHARD DUKELOW $\dagger$ \\ University of Minnesota, Grand Rapids, Minnesota, U.S.A. \\ (Received 7th December 1965, revised 7th January 1966)
}

\begin{abstract}
Summary. A flock of ninety ewes was divided into two groups and one group was orally drenched with ethylene dichloride extracted wheat germ oil (EDC-WGO) over two breeding seasons. In ewes drenched with EDC-WGO the lambing percentages of mated ewes increased by $12.9 \%$ and the number of ewes lambing by $7.6 \%$. In Guernsey cows given EDC-WGO there was no significant effect on the number of services per conception. The possible effects of oxygen uptake increasing components in EDG-WGO on early reproductive processes are discussed.
\end{abstract}

Isolation of octacosanol from ethylene dichloride extracted wheat germ oil (EDC-WGo) (Levin, Collins, Varner, Mosser \& Wolf, 1962) and the demonstration of the physiological effects of this compound on androgenic assays (Levin, 1963) and on oxygen utilization (Farrell, 1965), demonstrate the need for further study of EDC-WGO as an aid to breeding efficiency. Recent studies have been conducted on the effect of EDC-WGO on the reproductive efficiency of dairy cattle (Marion, 1962), hamsters (Soderwall \& Smith, 1962), bulls (Dukelow \& Erickson, 1964), swine (Dukelow, 1965) and mink (Dukelow, 1966). Thomas, La Grange \& Culbertson (1942) gave $60 \mathrm{ml}$ of cold-pressed wheat germ oil orally to sheep just before the breeding season and $10 \mathrm{ml}$ weekly thereafter until lambing. The lambing percentage (lambs born/100 ewes) in the control and treated groups was 137 and 133 respectively, the percentage of ewes which failed to lamb was $11 \%$ and $9 \%$. Marion (1962) fed EDC-WGo to 167 'repeatbreeder' dairy cows for 6 weeks beginning after two or more unsuccessful services. Seventy-three per cent of the cows conceived at the next service compared to $43 \%$ of the control cows.

The present study reports the effects of EDC-WGO on the reproductive efficiency of sheep and cattle.

Ninety ewes of the Minnesota-100 breed were paired by age and size, and placed in two groups. Ewes in the treated group received an oral drench $(30 \mathrm{ml})$ of EDC-WGO weekly from 3 weeks before the breeding season and continuing for two oestrous cycles. Control ewes received no drench. The trial was conducted during two breeding seasons. Rams were not treated. A

* Scientific Journal Series No. 5910. University of Minnesota, St. Paul.

$\dagger$ Present address: Department of Biochemistry, University of Georgia, Athens, Georgia, U.S.A. 
preliminary report of the first year's results has been reported (Dukelow \& Matalamaki, 1963).

Fifty-two Guernsey cows were paired according to age and past reproductive performance and placed at random in either treated or control groups. Treated cows received $30 \mathrm{ml}$ EDC-wGo over their grain twice weekly starting at 5 weeks post partum and continuing until each cow had not returned to oestrus within 30 days. Cows in the control group received an equal quantity of maize oil. All cows were artificially inseminated by one of three Guernsey bulls, one bull accounting for $50 \%$ of the inseminations and each bull being used equally between the two groups. All inseminations were carried out by the same technician. The data from both the sheep and the cattle trials were analysed by the analysis of variance.

A statistically significant difference $(P<0.05)$ was noted between the two groups in the number of lambs born/100 ewes mated and per 100 ewes lambing (Table 1). Differences between the two groups in the conception rate were not significant. Birth weights, while exhibiting the expected differences between

TABLE 1

MEAN VALUES OF REPRODUGTIVE GHARAGTERISTICS STUDIED IN EDC-WGO DRENCHED SHEEP

\begin{tabular}{l|c|c}
\hline \multicolumn{1}{c|}{ Factor } & Control & EDC-wGo \\
\hline No. of ewes & 90 & 90 \\
No. of ewes lambing & 79 & 83 \\
Percentage of ewes lambing & $87 \cdot 8$ & $92 \cdot 2$ \\
No. of lambs/100 ewes mated & 116 & 131 \\
No. of lambs/100 ewes lambing & 132 & 142 \\
& & \\
\hline
\end{tabular}

single and multiple births and between sexes, were not significantly different between treated and control groups.

Cows receiving EDC-WGO required 1.81 services/conception compared to 2.00 for the control cows. This difference was not statistically significant. Only six cows in the EDC-WGO fed groups were classed as 'difficult breeders'. In previous pregnancies these cows required 3 to 7 services but following EDC-WGO treatment five of them conceived at the first mating, and another at the second.

The finding that there was an increased number of lambs born/100 ewes mated $(12.9 \%)$ or per 100 ewes lambing $(7.6 \%)$ after drenching the ewes with EDC-WGO is in conflict with the report by Thomas et al. (1942) but it may be explained by the type of wheat germ oil used and the feeding regime employed. The site of action of active ingredients of wheat germ oil has not been determined, but its effect may be exerted on the process of ovulation, the viability of the ova in the oviduct or the developing embryo. Farrell (1965) demonstrated an increased oxygen uptake in rats receiving supplemental octacosanol produced from EDC-WGO which suggests an improved uterine environment favourable to germ cells and developing embryos. In the present study EDC-WGO was administered only during the early stages of the reproductive process, suggesting the positive effect is exerted during the stages of fertilization and implantation. 
Feeding EDC-WGO to dairy cattle of variable past reproductive performance did not result in improved reproduction. This does not imply that a beneficial effect could not be obtained using EDC-WGO as a therapeutic aid in cows with histories of reproductive problems as reported by Marion (1962). The results with the few cows in this trial classed as 'difficult breeders' supports the latter work.

The author wishes to thank Mr Ezra Levin, Viobin Corporation, Monticello, Illinois and Mr Wilbur Ahonen, Grand Rapids, Minnesota for assistance during the conduct of this study.

Addendum. Subsequent to the submission of this paper a communication from Dr C. V. Ross of the University of Missouri reported $15.9 \%$ and $8.4 \%$ increases in the lambing percentages of ewes mated and of ewes lambing respectively by the administration of EDC-wGO.

\section{REFERENCES}

Dukelow, W. R. (1965) Effects of ethylene dichloride extracted wheat germ oil in swine. J. Reprod. Fert. 10, 441 .

Dukelow, W. R. (1966) Effects of age of female, strain and ethylene dichloride extracted wheat germ oil on reproduction in mink (Mustela vison). f. Reprod. Fert. 11, 181.

Dukelow, W. R. \& ERICkson, W. E. (1964) The effect of ethylene dichloride extracted wheat germ oil on bulls used in artificial insemination. Proc. V. int. Congr. Anim. Reprod. artif. Insem. (Trento), IV, 601 .

Dukglow, W. R. \& Matalamaki, W. (1963) Effects of ethylene dichloride extracted wheat germ oil on the reproductive efficiency of the sheep. 7. Anim. Sci. 22, 1137.

FARRELL, P. R. (1965) The effects of octacosanol on conception and reproduction, on maintenance and growth of young, and on oxygen uptake in the white rat. M.S. thesis, Kansas State University, Manhatten Kansas, U.S.A.

Levin, E. (1963) Effects of octacosanol on chick comb growth. Proc. Soc. exp. Biol. Med. 112, 331.

Levin, E., Colzrns, V. K., Varner, D. S., Mosser, J. D. \& Wolf, G. (1962) Compositions comprising octacosanol, triacontanol, tetracosanol, or hexacosanol and methods employing same. U.S. Patent Office No. 3031376.

Marion, G. B. (1962) Effects of wheat germ oil on reproductive efficiency in repeat breeder cows. $\mathcal{J}$. Diary Sci. 45, 904.

Soderwall, A. L. \& SMrth, B. C. (1962) Beneficial effect of wheat germ oil on pregnancies in female golden hamsters (Mesocricetus auratus, Waterhouse). Fert. Steril. 13, 287.

Thomas, B. H., LaGrange, W. F. \& Culbertson, C. C. (1942) Effect of liberal wheat germ oil feeding on reproduction of several breeds of sheep. F. Anim. Sci. 1, 61 . 